\title{
ФОРМУВАННЯ КОМУНІКАЦІЙНОЇ ОСОБИСТОСТІ ПІД ВПЛИВОМ ІНДУСТРІї 4.0
}

ORCID ID: 0000-0002-7783-7146

Бондаренко Олена Іванівна к.психол.н, доцент, доцент кафедри міжнародних відносин і туризму Хмельницький національний університет Украӥна

Швидка модернізація інформаційно-комунікативних технологій в світі призвела до зростання можливостей їх застосування у всіх промислововиробничих галузях. Темпи таких змін прискорюються і $є$ ознакою сучасності. Матеріальний світ трансформується і стає дедалі складнішим. Зараз світ все частіше описується терміном VUCA [1] : Volatility (нестабільність), Uncertainty (невизначеність) Complexity (складність), Ambiguity (неоднозначність).

IКТ трансформують і можливості людини, розширюючи їх неймовірно за рахунок доступності інформації. Великі об’єми накопиченої інформації загострили питання оволодіння людиною такими обсягами інформації. Кількість даних, їх різноманітність, доступність отримання, швидкість обробки переходять в нову якість і дозволяють вирішувати багато завдань на принципово новому рівні. Тому оволодіння сучасними цифровими технологіями стає не просто необхідним, а життєво необхідним інструментом для людини.

Найважливішим компонентом нового уявлення про людський капітал стає активність людини, ії вміння швидко пристосовуватися до обставин, які постійно змінюються. Відбувається перехід до іншого типу праці, де на ряду із спеціалізованими знаннями i навичками, стають необхідними загальні «компетенції 21 століття» - когнітивні, інформаційно-комунікативні, соціальноемоційні. Особливу цінність набувають адаптивність до змін, вміння вчитися $\mathrm{i}$ швидко реагувати на нові запити ринку праці.

У відповідь на виникаючі нові потреби і завдання з'явилися нові поняття грамотності, які відкривають перспективи в сферах теорії, педагогіки, практики, 
політики і наукових досліджень. Нові вимоги до системи масової освіти були сформульовані з боку бізнесу. Вони з'явилися в зв'язку зі зміною структури ринку праці: частка рутинної роботи зменшувалася, а інтелектуальної - істотно зросла. Виник масовий попит на працю, що вимагає експертного аналізу або складної комунікації. Бізнес-асоціації стали наполягати на розвитку в освіті «м'яких навичок» або «універсальних навичок» («ключові компетентності», «навички XXI століття», «soft skills»), в тому числі навички самоорганізацї̈, комунікації, кооперації, колективного користування складних інструментів праці. Останнім часом високотехнологічні корпорації, продовжуючи дослідження ринку праці, заявляють про те, що зацікавлені в співробітниках, які вміють критично мислити і креативно вирішувати завдання, відкритих до нових знань та інноваційних підходів, здатних ефективно спілкуватися та працювати в команді (наприклад, Partnershipfor 21st Century Skills, 2006; Assessment and Teaching of 21 st Century Skills, 2012). Підвищення невизначеності майбутнього у зв'язку 3 розвитком та змінами інформаційно-комунікативних технологій висуває нові вимоги до результатів освіти - освіти, що триває все життя, вимагає формування вміння вчитися (learning to learn) і адаптуватися до нових умов. [2]

У зв'язку з цим виникають такі найважливіші питання: які навички, знання і установки необхідні для участі у цифровій економіці з максимальною вигодою для людини? Що потрібно, щоб ці навички, знання і установки відповідали високим темпам розвитку суспільства.

В останні роки під впливом цифрових технологій нового покоління спостерігається трансформація моделей діяльності в економіці та соціальній сфері. У зв'язку з просуванням таких технологій з'явилися проекти з розвитку економіки. Розвинені країни переходять в епоху четвертої промислової революції або «Індустрію 4.0», яку пов'язують зі злиттям технологій і стиранням кордонів між фізичними, цифровими і біологічними сферами. Великі дані, квантові технології, компоненти робототехніки і сенсорика, нейротехнології і штучний інтелект, нові виробничі технології, промисловий Інтернет, системи розподіленого реєстру, технології бездротового зв'язку, технології віртуальної і 
доповненої реальності - все це характеризує Індустрію 4.0. [3]

Пілотними країнами для реалізації Індустрії 4.0 стали Японія, США і Німеччина. Так, в Німеччині була сформульована стратегія «High Tech Strategy 2020 Action Plan», остання версія якої була опублікована в 2012 р. Повної інтернетизації промисловості німецькі підприємства планують досягти до 2030 р. Промисловці сформулювали концепцію Індустрії 4.0 і представили іï уряду. Ïї основу склали чотири принципи [4]: функціональна сумісність людини і машини, яка надає можливість контактувати безпосередньо через інтернет; прозорість інформації і здатність систем створювати віртуальну копію фізичного світу; технічна допомога машин людині для об'єднання великих обсягів даних і виконання ряду небезпечних для людини завдань; здатність систем самостійно $\mathrm{i}$ автономно приймати рішення.

Американська модель нової промислової реальності передбачає використання «Інтернету речей», його впровадження спричинить появу глобальних мереж, які об'єднають машини, системи управління і зберігання, а також виробничі потужності «розумних» заводів. На таких підприємствах можна реалізувати виробничі процеси будь-якої складності, при цьому буде зводитися до мінімуму ризик збоїв, забезпечуючи ефективне створення «розумних» продуктів. Однією з важливих складових подібних виробництв є бездротові мережі, які охоплюють всі процеси, машини, ресурси і співробітників, а також дозволяють налагодити обмін даними між компаніями. [5]

Своє бачення розвитку суспільства представив прем'єр-міністр Японії Сіндзо Абе на міжнародному ярмарку інформаційних технологій, телекомунікацій та програмного забезпечення (CеBIT) в Ганновері в стратегії «Society 5.0» в березні 2017 року. Суспільство 5.0 було запропоновано в П'ятому базовому плані з науки і технологій як суспільство майбутнього, до якого Японія повинна прагнути. Суспільство 5.0 слідує за інформаційним суспільством (суспільство 4.0). Це суспільство, орієнтоване на людину, яка врівноважує економічний прогрес з вирішенням соціальних проблем за допомогою системи, яка тісно об'єднує кіберпростір і фізичний простір. У Society 5.0 величезна 
кількість інформації від датчиків у фізичному просторі накопичується в кіберпросторі, де ці великі дані аналізуються штучним інтелектом, і результати аналізу передаються людям в фізичному просторі в різних формах. [6]

Цифрові сервіси та сучасний підхід до розвитку «розумних» просторів змінюють умови життя людини на більш комфортні. «Розумний» простір являє собою фізичне та цифрове середовище, де люди і технологічні системи відкрито взаємодіють в пов'язаних і скоординованих інтелектуальних екосистемах. Серед прикладів такого роду - «розумні» міста, «розумні» будинки, цифрові робочі місця і фабрики. Сьогодні світ вступає в період прискореного надання надійних «розумних» просторів, коли технології стають невід'ємною частиною повсякденного життя людини в будь-якій його ролі - працівника, клієнта, члена спільноти, громадянина.

«Розумне» суспільство формує нові цінності - орієнтація на потреби людини, гнучкість і креативність. Сьогодні, одним з головних викликів стає зростання кількості, якості та різноманіття взаємозв'язків між організаціями, громадянами та соціально-економічними системами, що супроводжується динамікою числа трансакцій і обсягів даних і приводить до більш складної i синхронізованої інтеграції «всіх з усіма». Під впливом цифровізації кардинально змінюються ринок праці, охорона здоров'я, освіта, просторовий розвиток. [7]

Перебудова промисловості і суспільства під впливом четвертої промислової революції характеризується мультидисциплінарністю, глибиною змін, які охоплюють всі сфери людського життя, а також трансформацією уявлень про саму людину і іï завдання.

В умовах цифрової економіки необхідно забезпечити відповідну динаміку і підвищення якості людського капіталу. Інтенсивне зростання обсягів даних значно перевищує здатність людини до їх засвоєння, що визначає попит на технології штучного інтелекту і електронні пристрої. Їх удосконалення робить користувача більш уразливим що, в свою чергу, породжує попит на розвиток технологій інформаційної безпеки. Збільшення швидкості обміну інформацією та іiі застосування вимагає підвищення інформаційної грамотності населення, 
нових навичок і компетенцій, готовності використовувати нові технології в повсякденному житті. Особливого значення набуває формування освітніх програм, що відповідають глобальним трендам, траєкторіям навчання, здатних забезпечити «цифрову компетентність».

Таким чином, під впливом більш складного зовнішнього середовища змінюються вимоги до комунікаційної особистості людини. Розглянемо деякі моделі такої особистості, які описують навички 21 століття.

Цифрові компетенції - це загальний термін, який використовується для характеристики здібностей людини використовувати інформаційнокомунікаційні технології в певному контексті.

У доповіді Світового банку про світовий розвиток «Цифрові дивіденди» [8] всі види навичок цифрової економіки об'єднані в три групи:

Когнітивні - грамотність і математичні навички, а також когнітивні навички більш високого рівня (наприклад, логічне і креативне мислення); вміння вирішувати проблеми, а не знання, необхідне для вирішення проблем; вербальна грамотність, пам'ять і швидкість мислення;

Соціальні та поведінкові - готовність отримувати новий досвід, сумлінність, екстраверсія, такт i емоційна стабільність, готовність до компромісів, прийняття рішень і навички міжособистісного спілкування;

технічні - знання методів, вміння працювати з матеріалами, механізмами та інструментами; технічні навички, набуті в процесі навчання або професійної підготовки після закінчення середньої школи, або в процесі трудової діяльності; навички, необхідні для роботи за конкретною професією.

Всесвітній Економічний форум (World Economic Forum) для успішної роботи в умовах четвертої промислової революції виділяє наступні навички [9]: комплексне рішення проблем, критичне мислення, креативність, управління людьми, вміння працювати 3 людьми, навички координації, взаємодія, емоційний інтелект, судження i швидкість прийняття рішень, клієнтоорієнтованість (сервісна орієнтація - Service Orientation), здатність узгодження i ведення переговорів, когнітивна гнучкість. При цьому 
наголошується, що через п'ять років понад третини навичок (35\%), які вважаються важливими в сучасній робочій силі, зміняться.

Модель фундаментальних навичок цифрової економіки (The New Foundational Skills of the Digital Economy) розроблена компанією Burning Glass [10] і виділяє чотири блоки навичок, в рамках яких визначаються відповідні переліки фундаментальних навичок: особистісні навички (Human Skills) аналітичне мислення, творчий підхід, критичне міркування, комунікації та співпраця; базові знання за сферами (Domain Knowledge) - стратегія, економіка, маркетинг, комунікації / зв'язки з громадськістю, розвиток талантів / управління людськими ресурсами, дослідження і розробка продукту; цифрові навички (Digital Building Block Skills) - аналіз даних, Big Data i управління даними, розробка програмного забезпечення, забезпечення інформаційної безпеки; навички бізнес-продажу (Business Enabler Skills) - управління проектом, прийняття рішень, візуалізація і передача даних.

У даній моделі також виділяються рівні розвитку компетенцій:

- базові компетенції (Baseline Competencies) надають можливість розуміти i орієнтуватися в широкому розмаїтті ролей, проблем і можливостей. Вони формують платформу, на якій люди можуть накопичити додатковий досвід для розвитку нових компетенцій та отримання кваліфікації для більш технічно розвинених робочих місць в майбутньому;

- ключові компетенції (Core Competencies) засновані на базових компетенціях і необхідні для отримання більш високооплачуваної роботи в більш спеціалізованих галузях. На відміну від базових компетенцій, які 3 меншою ймовірністю кардинально зміняться в найближчому майбутньому, ключові компетенції згодом розвиваються, що вимагає постійного навчання протягом всієї кар'єри;

- відмінні компетенції (Distinguishing Competencies) - це висококваліфіковані здатності, засвоєні фахівцями-практиками, часто в певному підрозділі компанії або в певній галузі навичок. Вони засновані на базових і основних компетенціях, і їх цінність найбільш висока, оскільки їх 
пропозиція невелика i вони дозволяють командам і організаціям досягати більш складних і важких цілей.

Модель цифрових компетенцій DigComp 2.1 [11] містить 21 компетенцію, об’єднаних у п’ять блоків.

1. Компетенції в сфері інформаційної грамотності та вміння працювати 3 даними (Information and Data Literacy Competence): перегляд, пошук та фільтрація даних, інформації та цифрового контенту; оцінка даних, інформації та цифрового контенту; управління даними, інформацією та цифровим контентом.

2. Компетенції в сфері комунікації та взаємодії (Communication and Collaboration Competence): взаємодія за допомогою цифрових технологій; використання відповідних засобів цифрового зв’язку для заданого контексту; обмін інформацією та контентом за допомогою цифрових технологій; контактувати iз суспільством, користуватися державними та приватними послугами завдяки використанню цифрових технологій; шукати можливості для самовдосконалення та громадянської участі за допомогою відповідних цифрових технологій володіти правилами поведінки та етикету в цифровому середовищу; управління цифровою ідентичністю, тобто вміння створювати та управляти аккаунтами.

3. Компетенції у створенні цифрового контенту (Digital Content Creation Competence): створення цифрового контенту; вміння змінювати, покращувати, інтеграція та створення цифрового контенту; обізнаність щодо авторських прав та політики ліцензування відносно даних, інформації та цифрового контенту; програмування, тобто вміння писати програмний код.

4. Компетенції в сфері безпеки(Safety Competence): захист пристроїв та контенту, знання заходів безпеки, розуміння ризиків та загроз; захист персональних даних та конфіденційності; знання та навички для збереження свого здоров'я та інших з точки зору як екології використання цифрових технологій, так і ризиків, загроз безпеці громадян; розуміння впливу цифрових технологій на екологію, навколишнє середовище. 
5. Компетенції у вирішенні проблем (Problem Solving): вирішувати технічні проблеми, що виникають із комп’ютерною технікою, програмним забезпеченням, мережами; визначати потреби та знаходити відповідні технічні рішення, або кастимізувати цифрові технології до власних потреб; індивідуальне або колективне креативне використання цифрових технологій у створенні нової інформації та продукту для розуміння та вирішення концептуальних проблем і ситуацій в цифрових середовищах; вміння самостійно визначати потребу в отриманні додаткових нових цифрових навичок.

Дана модель містить розгорнуті оціночні шкали з 8 рівнів кваліфікацій EQF. Встановлюються такі рівні розвитку компетенцій: базовий (Foundation), відповідний 1 і 2 рівням кваліфікації, проміжний (Intermediate) - 3 і 4 рівні, просунутий (Advanced) - 5 і 6 рівні, високоспеціалізований (Higly Specialised) - 7 і 8 рівні кваліфікації.

Рамки DigComp, були розроблені за участю великої кількості експертів і отримали схвалення на європейському рівні. Перевагою DigComp є їх гнучкість і можливість застосування в різних сферах діяльності - в бізнесі для підвищення кваліфікації співробітників і в освіті при підготовці фахівців різних спеціальностей. Свропейська комісія в червні 2016 р запустила програму «Нові навички: порядок денний для Європи». В одній з ініціатив Порядку денного під назвою «Шляхи підвищення кваліфікації: нові можливості для дорослих» DigComp визнані довідковим інструментом для загального розуміння цифрової компетенції для громадян. [12]

Оскільки питання впровадження у навальних закладах у різних країнах нових компетенцій відбувається не рівномірно, тому спостерігається матеріальний, інтелектуальний i технологічний розрив між людьми, організаціями і країнами. На це впливають різні фактори: економічний розвиток країни, фінансування освіти і науки, кадрове та інституціональне забезпечення, соціально-економічна політика держави.

Ключовим фактором успіху процесів цифровізації $\epsilon$ наявність висококваліфікованих кадрів в достатньому обсязі і відповідних робочих місць, 
а також системи підготовки фахівців, що володіють певними компетенціями для розробки i впровадження цифрових технологій. Так в країнах 3 високим показником ВВП на душу населення та інноваційною економікою частка висококваліфікованих працівників є найвищою в світі, від 22\% до 45\%, при середньому показнику 15\% по світу в цілому.

Ця закономірність свідчить про те, що без розвитку людського капіталу не будуть можливі ні подальший технічний прогрес, ні рішення соціальнодемографічних проблем, ні відповідні культурні перетворення.

Таким чином, в умовах випереджального розвитку технологій і постійних ринкових перетворень для зростання економіки необхідно забезпечити відповідну динаміку і підвищення якості комунікаційної особистості людини. Цифровізація вимагає формування нових компетенцій на ринку праці, що тягне за собою перебудову всієї системи освіти. Тому сьогодні в центрі порядку денного в усьому світі стоїть питання про новий зміст освіти. Інтенсивність змін залежить від того, наскільки швидко і ефективно можна трансформувати наявні структури і адаптувати існуючі методики освіти до дійсності, яка постійно ускладнюється, і до нових засобів, розроблених для вирішення проблем.

\section{Список використаних джерел}

[1] Business Horizons: Bennett, N., \& Lemoine, G. J. (2014). What a difference a word akes: Understanding threats to performance in a VUCA world., Business Horizons 57(3), 311-317. Вилучено 3: https://www.researchgate.net/ publication/260313997_What_a_difference_a_word_makes_Understanding_thr eats_to_performance_in_a_VUCA_world/citation/download

[2] Вклад в будущее: Компетенции 21 века в национальных стандартах школьного образования / Аналитический обзор. Вилучено з: https://sch2083.mskobr.ru/files/na_zametku_uchitelyu_kompetencii_21_veka_v _nacional_nyh_standartah_shkol_nogo_obrazovaniya.pdf

[3] Мезина Т.В. Предпосылки внедрения концепции «Индустрия 4.0». Вилучено 3: http://www.nauteh-journal.ru/files/7e638ca1-4847-4b1d-a274- 


\section{$312 f 34601017$}

[4] Стратегические решения и риск-менеджмент: Тарасов И. В. Технологии индустрии 4.0: влияние на повышение производительности промышленных компаний. Вилучено 3: https://www.jsdrm.ru/jour/article/view/772/645

[5] Control Engineering Россия: Швецов Д. У истоков «Индустрии 4.0»: как развивается промышленность Германии. Вилучено з: https://controlengrussia.com/industry-4-0/germaniya/

[6] CAO.GO: Society 5.0? Вилучено 3: https://www8.cao.go.jp/cstp/english/society5_0/index.html

[7] Что такое цифровая экономика? Тренды, компетенции, измерение: докл. к $\mathrm{XX}$ Апр. междунар. науч. конф. по проблемам развития экономики и общества, Москва, 9-12 апр. 2019 г. Вилучено 3: https://www.hse.ru/ data/2019/04/12/1178004671/2\%20Цифровая єкономика.pdf

[8] Доклад о мировом развитии. Цифровые дивиденды. Вилучено з: https://data.gov.ru/sites/default/files/documents/vsemirnyy_bank_2016_god.pdf

[9] The Future of Jobs Employment, Skills and Workforce Strategy for the Fourth Industrial Revolution. Вилучено 3: http://www3.weforum.org/docs/WEF_FOJ_ Executive_Summary_Jobs.pdf

[10] The New Foundational Skills of the Digital Economy. Developing the Professionals of the Future. Вилучено 3: https://www.burning-glass.com/wpcontent/uploads/New_Foundational_Skills.pdf

[11] DigComp 2.1. The Digital Competence Framework for Citizens. With Eight Proficiency Levels and Examples of Use. Вилучено 3: http:// publications.jrc.ec.europa.eu/repository/ bitstream/JRC106281/webdigcomp2.1pdf

[12] DigComp 2.1. The Digital Competence Framework for Citizens. With Eight Proficiency Levels and Examples of Use. Вилучено 3: http:// publications.jrc. ec.europa.eu/repository/ bitstream/JRC106281/webdigcomp2.1pdf 